J. Perinat. Med. 17 (1989) 297

\section{Prenatal ultrasonographic diagnosis of thoracopagus conjoined twins}

\author{
Víctor H. Quiroz', Waldo H. Sepúlveda ${ }^{1,4}$, María Mercado², Rubén Bermúdez ${ }^{3}$, \\ Rodrigo Fernández ${ }^{1}$, and Jorge Varela ${ }^{1}$
}

${ }^{1}$ Departments of Obstetrics and Gynecology, ${ }^{2}$ Pediatrics, and ${ }^{3}$ Cardiology, "Guillermo Grant Benavente" Hospital, and ${ }^{4}$ Department of Histology and Embryology, University of Concepción, Concepción, Chile

\section{Introduction}

The term "conjoined twins" is applied to those infants who are united at some point of their body as a result of incomplete fission of the embryonic disc before the third week of pregnancy. They are classified according to the anatomical site of union in: 1) thoracopagus joined at the chest, 2) xiphopagus - joined at the lower sternum and/or upper abdomen, 3) pygopagus - joined at the buttocks, 4) ischiopagus - joined at the ischium, and 5) craneopagus - joined at the head $[4,20]$. Thoracopagus twins, the most common form of conjoining, account for approximately $75 \%$ of the cases $[4$, $5,20]$. From the developmental point of view, they originate from a single ovum and belong to the monochorionic-monoamniotic type of monozygotic twins [4, 20].

The earliest case on record seems to be in England in A. D. 1.100 [1, 22], and the most famous ones are the "siamese twins" Chang and Eng Bunker, who were born in 1811 in Siam (now Thailand), were exhibited worldwide and died at the age of 63 [10]. In the past, conjoined twins were only occasionally suspected prenatally by means of roentgenographic studies [3], whereas at present, the diagnosis is usually made by ultrasound $[7,8,12,17]$. In a 1 -year period, the authors have encountered two cases of thoracopagus conjoined twins, both dignosed prenatally by ultrasound. Since the estimated incidence of such cases is $1 / 50.000$ to $1 / 60.000$ deliveries $[4,9,20]$ or $1 / 650$ to $1 / 900$ twin deliveries [20], documentation of new cases and discussion

\section{Curriculum vitae}

VICTOR H. QUIROZ, born in 1947, received his medical diplome from the University of Chile in 1971. Since then he is working at the Department of Obstetrics and Gynecology, "Guillermo Grant Benavente" Hospital, University of Concepción, obtaining his specialist's qualification

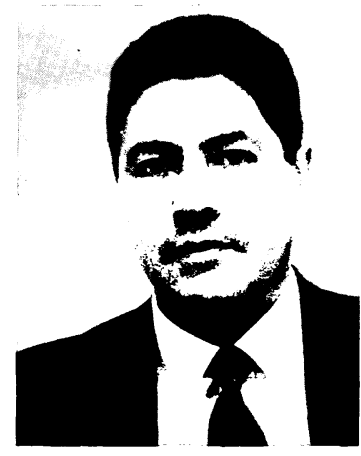
in 1974. His area of interest is ultrasound diagnosis in Obstetrics and Gynecology, realizing studies in this field in Valencia, Spain, in 1983.

of their management is, therefore, of great value. At "Guillermo Grant Benavente" Hospital the only one previous case occurred in November, 1966 [11], and from our country only two cases of thoracopagus twins have been reported [16].

\section{Case reports}

Case 1: A 35-year-old woman, gravida 3, para 2 , was referred at 28 weeks' gestation for ultrasound examination because of suspected multiple pregnancy. Ultrasound demonstrated male twins in breech position, lying parallel and at the same level, facing each other and with an abnormal curvature of the cervico-thoracic spine in one of 
the twins. Their ventral part was fusioned from the umbilicus to the chest and only a fusioned heart and a common liver could be demonstrated (figure 1). There was a moderate hydramnios, no separating membrane between the twins and a four-vessel umbilical cord. The pregnancy was allowed to continue until term with no significant prenatal complications and under frequent ultrasound examinations. At 38 weeks' gestation, an elective cesarean section was performed, with the delivery of male thoracopagus twins with a combined weight of 5.720-g and Apgar score of 8 and 9 at 1 and 5 minutes, respectively (figure 2). Initial electrocardiogram and angiographic studies of the infants revealed a single cardiac activity and two distinct hearts fusioned at the level of the ventricles. The infants died 52 hours after birth because of cardio-respiratory insufficiency and, at autopsy, the ultrasound findings were confirmed as well as a triventricular fusioned heart with a common pericardium, transposition of the great vessels, an atrophic pulmonary artery, and independent gastrointestinal tracts.

Case 2: A 30-year-old woman, gesta 2, para 1, was referred at 22 weeks' gestation because of discrepancy between gestational age and uterine size. Her past medical history was unremarkable and no other complications during the current pregnancy were noted. Ultrasound examination revealed conjoined twins in which similar findings to the above were found (figures 3,4 ), but in this case the twins were female and the amniotic fluid volume was normal. The subsequent prenatal course was uneventful, and an elective cesarean section was performed at 37 weeks' gestation, with the delivery of female thoracopagus twins with a combined weight of $4.300-\mathrm{g}$ and Apgar score of 8 and 9 at 1 and 5 minutes, respectively (figure 5). Simultaneous electrocar-

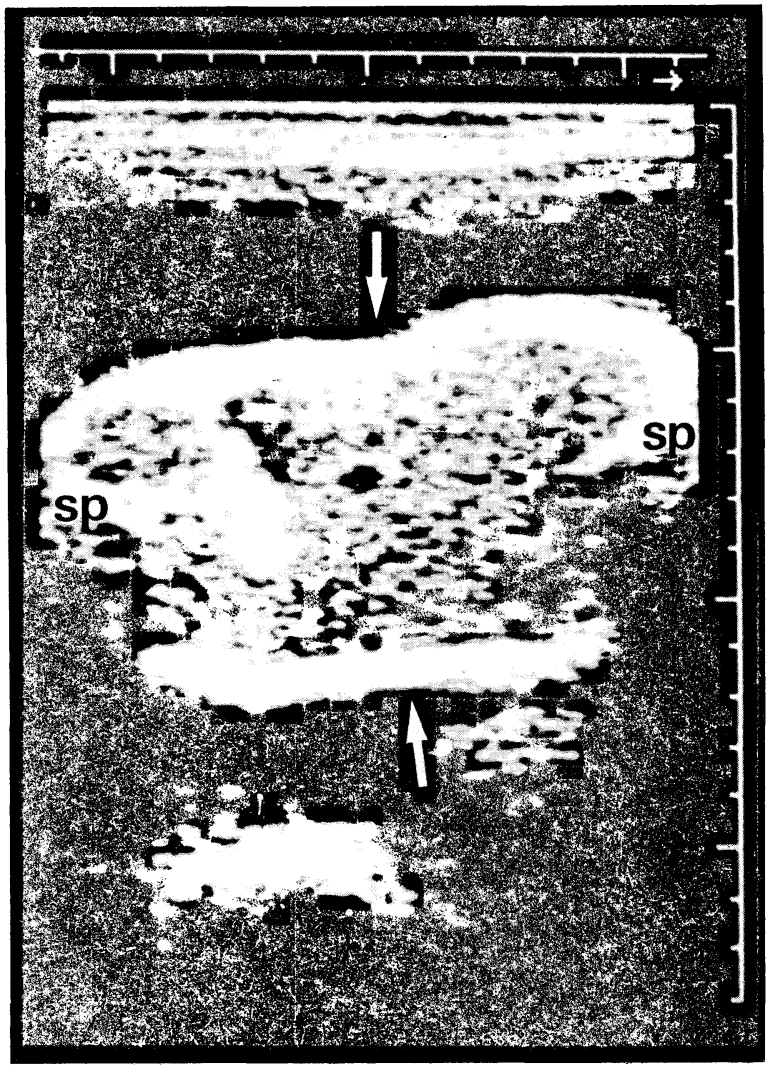

Figure 1. Transverse sonogram through abdomen of thoracopagus conjoined twins demonstrating a common liver. Note continuous skin outline with no separating space between the twins (arrows). $\mathrm{sp}=$ fetal spines. 


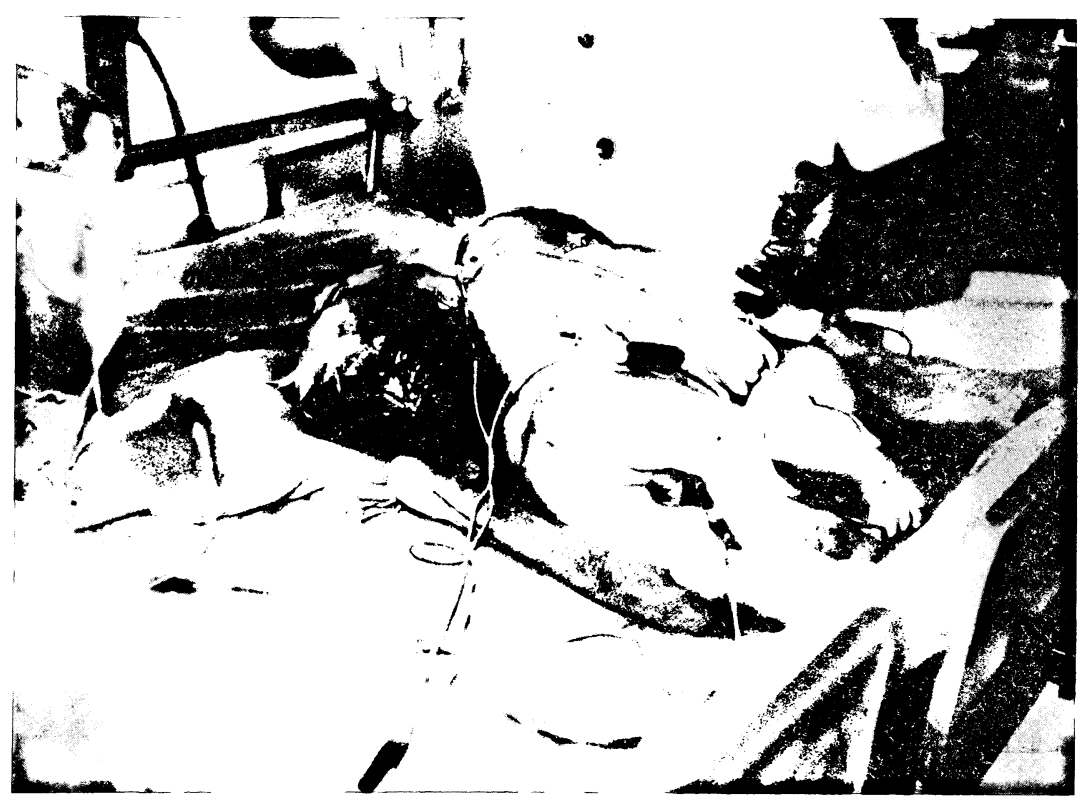

Figure 2. Male thoracopagus twins soon after birth. Note the backward flexion of the cervical spine of the twin on left.

diogram taken immediately after birth confirmed a fusioned heart. The infants died on the 7 th day of life because of progressive impairment of their respiratory function. Further studies and autopsy were refused by the parents.

\section{Discussion}

The antepartum diagnosis of conjoined twins is obviously essential for a proper obstetrical and perinatal management. Unfortunately, the diagnosis is often missed unless this possibility is entertained. Since twin pregnancies are increasingly diagnosed prenatally by ultrasound, several authors $[7,12,17,20]$ have stressed the role of careful examination of all identified twins in order to rule out conjoining whenever multiple pregnancy is diagnosed. This is specially true in those cases in which no separating membrane is demonstrated. The prenatal diagnosis of conjoined twins by ultrasound was first reported by WILSON et al. [21], and since then this method has proved its crucial role not only in the diagnosis but also in establishing the degree of conjoining, allowing to make the fetal prognosis as well as determine the possibility of postnatal surgical separation $[2,6-8,12,14,17,19-22]$.
The ultrasound criteria for the antepartum diagnosis of conjoined twins have been pointed out by KooNTZ et al. [12]: 1) lack of separating membrane between the twins, 2) inability to separate the fetal bodies, 3) detection of fetal anomalies, 4) more than three vessels in a single umbilical cord, and 5) ultrasonographic identification of any of the classic radiological signs of thoracopagus conjoined twins (both fetal heads at the same level and body plane, an unusual extension and/or proximity of the spines, and no change in relative positions after movements or manipulation of the fetuses or the passage of time [3]).

The ultrasound diagnosis of conjoined twins has been usually made in the second half of pregnancy, the main reason for referral being the clinical suspicion of multiple pregnancy or a uterine size larger than expected for dates $[2,6-8$, $12,14,17,19-22]$. Occasionally, the diagnosis has been made incidentally even in the first trimester, during routine assessment of gestational age $[13,18]$. Once the diagnosis is made, is important to establish the extent of conjoining, since survival depends on the site of union and the resultant fusion of vital organs. In all documentated cases of thoracopagus twins the liver 


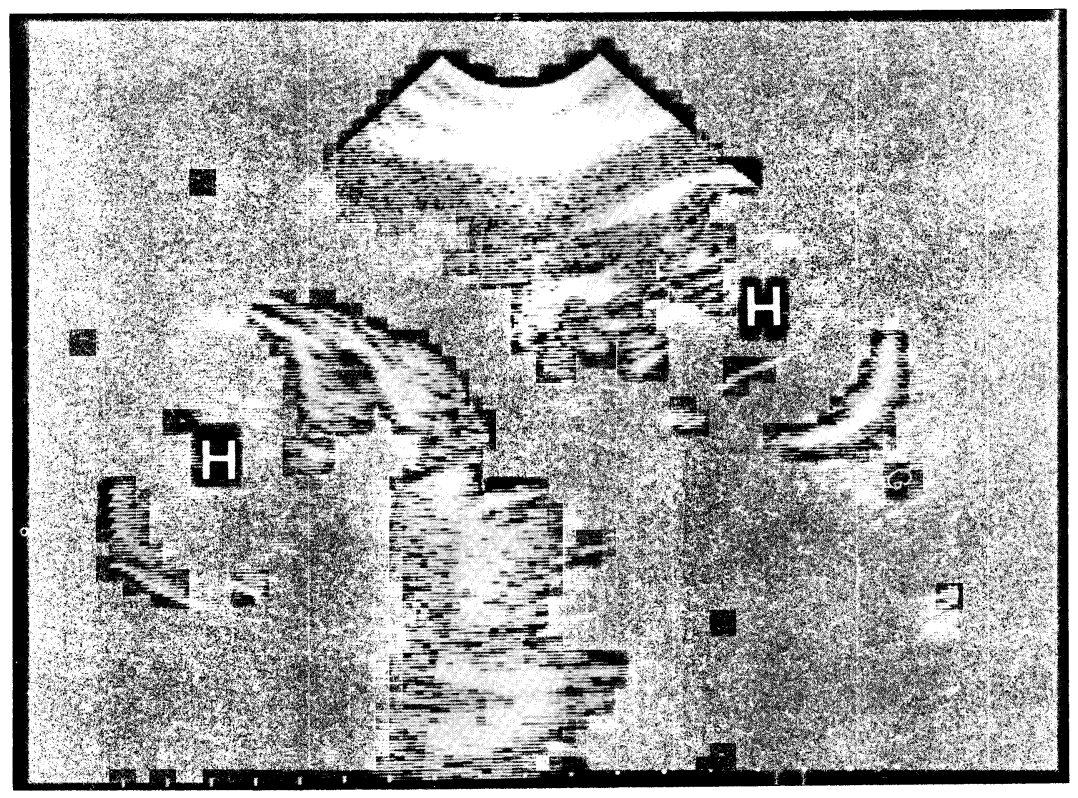

Figure 3. Transverse sonogram showing separate fetal heads $(\mathrm{H})$ with hyperextension. Twins are facing each other.

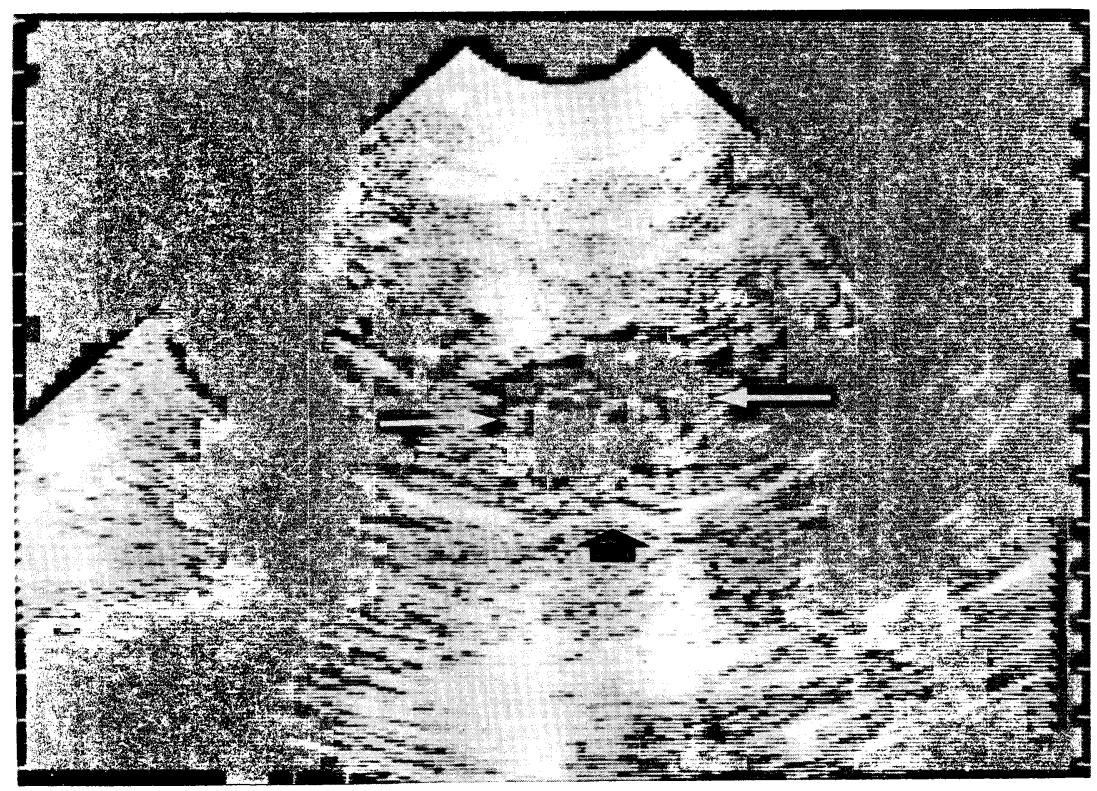

Figure 4. Transverse sonogram through fetal thorax demonstrating fusioned hearts (white arrows). Black arrow shows continuous skin outline.

is found to be common, with a common pericardial sac in $90 \%$, a fusioned heart in $75 \%$ and a common gastrointestinal tract in $50 \%[5,7$, 15]. Therefore, special attention must be payed to the cardiac structures since fetal prognosis depends mainly on severity of fusion and anomalies of the hearts [5, 15]. However, a complete individual assessment can only be achieved in 


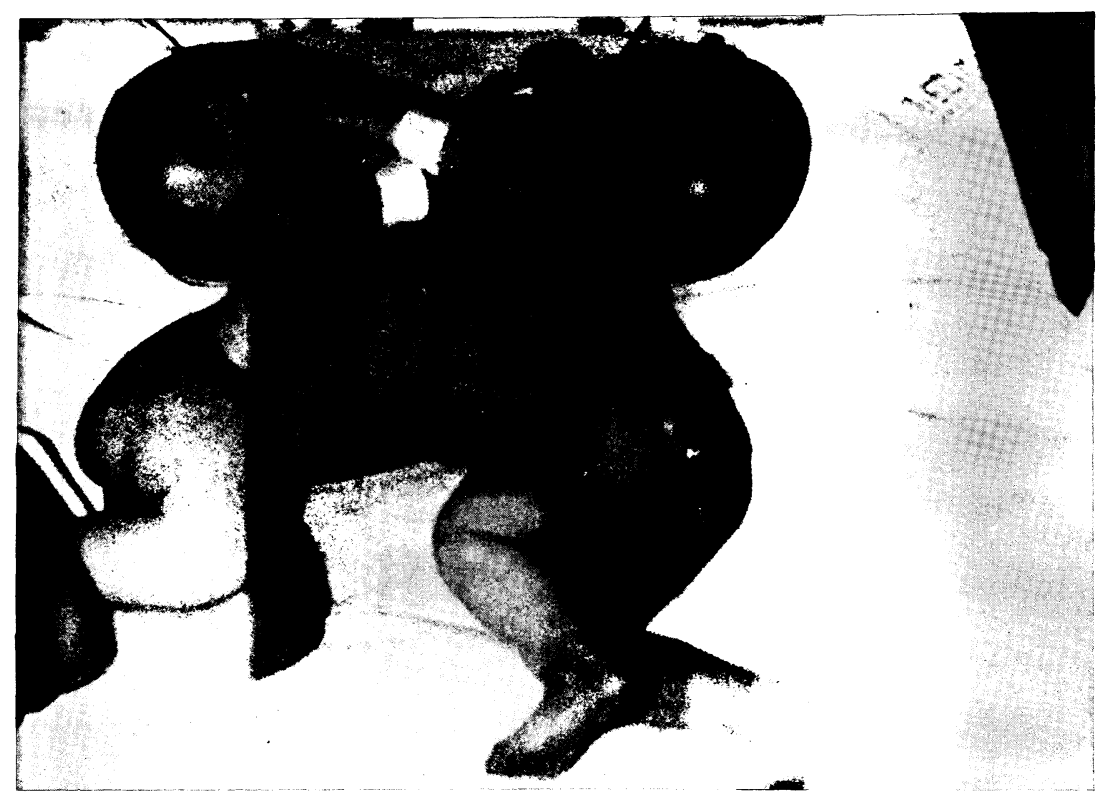

Figure 5. Female thoracopagus twins.

the neonatal period by a multiprofessional team, in order to determine the final prognosis and the possibility of surgery. In relation to the route of delivery, the best choice is an elective cesarean section avoiding both fetal and maternal trauma $[7,8,17,20]$. However, this is not valid if pregnancy termination is chosen or the fetuses are small enough that can pass through the vaginal canal without damaging the mother $[8,17,20]$.

As our cases demonstrate, the ultrasound diagnosis of conjoined twins is not difficult. We were able to diagnose this anomaly in the first ultrasound examination and the vital organs that the infants shared were clearly established. Both of our cases were diagnosed in the second trimester, at 28 and 22 weeks' gestation respectively, and strongly suggestive of thoracopagus twins were the inability to separate the fetal bodies at the level of their ventral portion, the discovery of fusioned hearts with syncronic beats and a faceto-face fetal position with a backward flexion of the cervical spines. Unfortunately, there was practically no possibility of neonatal surgery because the hearts were fusioned in both cases, which was the main cause of the final outcome of the infants.

In summary, the careful ultrasound examination of all identified sets of twins is the cornerstone of the prenatal diagnosis of conjoined twins, which is essential for planning a rational and appropriate obstetrical and perinatal management.

Parent counseling in the perinatal period is also desirable, to prepare them for the final outcome of the infants and to conform them with the fact that there is no known case of recurrence [17].

\begin{abstract}
Conjoined twins are a rare obstetric event occurring $1 / 50.000$ to $1 / 60.000$ deliveries as a result of incomplete fission of the embryonic disc before the third week of pregnancy. They belong to the monochorionicmonoamniotic type of monozygotic twins and are classified according to the area of union, the most common site being the chest and upper abdomen (thoracopagus).
\end{abstract}

Reported are two cases of thoracopagus twins in which the diagnosis was made prenatally by ultrasound in the second trimester of pregnancy. The most significant ultrasound findings included the demonstration of a single cardiac activity, the inability to separate the fetal bodies at their ventral portion, and a face-to-face fetal position. The pregnancies were allowed to continue until term with no significant prenatal complications, 
and an elective cesarean section was performed to avoid a traumatic delivery. In both cases the infants died during the first week of life because of cardiorespiratory insufficiency.

The ultrasound criteria for the antenatal diagnosis of conjoined twins are reviewed, concluding that the careful ultrasound examination of all identified sets of twins, specially in those cases in which no separating membrane is demonstrated, is the cornerstone in making the prenatal diagnosis. In addition, ultrasound plays a crucial role not only in the diagnosis, but also in establishing the degree of conjoining, which is essential for planning an appropriate obstetrical and perinatal management.

Keywords: Conjoined twins, fetal diseases, prenatal diagnosis, ultrasound diagnosis.

\section{Zusammenfassung}

Pränatale sonographische Diagnose eines Thorakopagus Durch Mißbildung miteinander verwachsene Zwillinge kommen in der Geburtshilfe mit einer Inzidenz von $1 / 50000$ bis $1 / 60000$ Entbindungen sehr selten vor. Zugrunde liegt eine unvollständige Spaltung der Keimscheibe vor der dritten Schwangerschaftswoche. Die Anlage der stets eineiigen Zwillinge ist monoamniotisch-monochoriatisch. Ihre Klassifikation erfolgt je nach Sitz der Verwachsung, wobei die Verbindung zwischen Brust und oberem Abdomen am häufigsten vorkommt (Thorakopagus).

Wir berichten über zwei Fälle solcher mißgebildeten Zwillinge, bei denen die Diagnose sonographisch im zweiten Schwangerschaftstrimenon gestellt wurde. Dabei waren die wichtigsten Ultraschallbefunde die Darstellung nur einer Herzaktion, die nicht mögliche Trennung der Körperumrisse in ihrem ventralen Anteil sowie Gegenüberstellung der Gesichter der Feten. Die
Schwangerschaften wurden bis zum Termin ohne gröBere Komplikationen fortgeführt. Um traumatisierende Entbindungen zu vermeiden, wurde dann elektiv sektioniert. In beiden Fällen starben die Kinder in der ersten Lebenswoche an einer cardio-pulmonalen Insuffizienz.

Es wurde die sonographischen Kriterien für die antenatale Diagnose von miteinander verwachsenen Zwillingen genannt. Alle Zwillingspaare müssen per Ultraschall sorgfältig untersucht werden, besonders aber diejenigen, wo sich keine trennende Membran darstellen läßt. Dies ist die Grundlage der pränatalen Diagnose. Darüberhinaus ist der Ultraschall nicht nur für die Diagnose entscheidend, sondern auch um das Ausmaß der Verwachsung festzulegen, damit ein adäquates geburtshilfliches und perinatales Management geplant werden kann.

Schlüsselwörter: Fetrale Erkrankungen, pränatale Diagnose, Ultraschalldiagnostik, verwachsene Zwillinge.

\section{Résumé}

\section{Diagnostic échographique prénatal de jumeaux conjoints thoracopages}

Les siamois représentent une éventualité exceptionnelle en obstétrique survenant une fois pour 50000 à 60000 naissances; ils résultent d'une séparation incomplète du disque embryonnaire avant la troisième semaine de grossesse. Ils font partie des jumeaux monozygotiques monochoriaux monoamniotiques et on les classe selon la zone d'union; le site le plus habituel est le torse et la partie supérieure de l'abdomen (thoracopage).

Nous rapportons les deux cas de jumeaux thoracopages pour lesquels le diagnostic avait été porté en prénatal par échographie au cours du second trimestre de la grossesse. Les aspects échographiques les plus significatifs comprennent la mise en évidence d'une activité cardiaque unique, l'impossibilité de séparer les corps foetaux dans leur portion ventrale, et la position face contre face. On a autorisé la poursuite des gros- sesses jusqu'au terme sans complication prénatale significative, et une césarienne a été effeczuée afin d'éviter un accouchement traumatique. Dans les deux observations les enfants sont décédés au cours de la première semaine de vie en raison d'une insuffisance cardio-respiratoire.

Les critères échographiques du diagnostic prénatal de jumeaux siamois sont passés en revue, et l'on en conclue que le fondement du diagnostic prénatal est l'examen échographique soigneux de toute paire de jumeaux diagnostiquées, et tout particulièrement celles pour lesquelles il n'existe pas de membrane de séparation.

En outre, l'échographie joue un rôle crucial non seulement pour le diagnostic, mais encore pour établir de degré de fusion, ce qui est essentiel pour plannifier une prise en charge appropriée tant obstétricale que périnatale.

Mots-clés: Diagnostic échographique, diagnostic prénatal, jumeaux siamois, maladie foetale. 


\section{References}

[1] AIRD I: The conjoined twins of Kano. Br Med J 1 (1954) 831

[2] Austin E, BS Schifrin, JJ Pomerance, SL Gans, MS KOMAIKO: The antepartum diagnosis of conjoined twins. J Pediatr Surg 15 (1980) 332

[3] BORDEN S, RF RIDER, JJ POLlaRd, WH HENDREN: Radiology of conjoined twins. Intrauterine diagnosis and postnatal evaluation. Am J Roentgenol 120 (1974) 424

[4] DINNER M: A review of the problem of conjoined twins. S Afr Med J 42 (1968) 409

[5] Edwards WD, DR Hagel, J THOMPSON, CM Whorton, JE EDWARDS: Conjoined thoracopagus twins. Circulation 56 (1977) 491

[6] FAGAN CJ: Antepartum diagnosis of conjoined twins by ultrasonography. Am J Roentgenol 129 (1977) 921

[7] Fitzgerald EJ, A ToI, DL Cochlin: Conjoined twins. Antenatal ultrasound diagnosis and a review of the literature. Br J Radiol 58 (1985) 1053

[8] Gore RM, RA FILly, JT PARER: Sonographic antepartum diagnosis of conjoined twins. Its impact on obstetric management. JAMA 247 (1982) 3351

[9] HANSON JW: Incidence of conjoined twinning. Lancet 2 (1975) 1257.

[10] Harper RG, K Kenigsberg, CG Sia, D Horn, D STERN, V BongIOVI: Xiphopagus conjoined twins: A 300-year review of the obstetric, morphopathologic, neonatal, and surgical parameters. Am J Obstet Gynecol 137 (1980) 617

[11] Henning E: Personal communication (1989).

[12] Koontz WL, WNP Herbert, JW SeEDS, RC CEFALO: Ultrasonography in the antepartum diagnosis of conjoined twins. A report of two cases. J Reprod Med 28 (1983) 627

[13] Maggio M, NA Callan, KA Hamod, RC SandERS: The first-trimester ultrasonographic diagnosis of conjoined twins. Am J Obstet Gynecol 152 (1985) 833
[14] Morgan CL, WS Trought, G Sheldon, TK BARTON: B-scan and real-time ultrasound in the antepartum diagnosis of conjoined twins and pericardial effusion. Am J Roentgenol 130 (1978) 578

[15] Patel R, K Fox, J Dawson, JFN Taylor, GR GRAHAM: Cardiovascular anomalies in thoracopagus twins and the importance of preoperative cardiac evaluation. Br Heart J 39 (1977) 1254

[16] Rubio R, JF Alba, L Yañez, J Gonzalez: Dos casos clínicos de monstruosidad fetal (toracópagos). Rev Chil Obstet Ginecol 41 (1976) 195

[17] SaKala EP: Obstetric management of conjoined twins. Obstet Gynecol 67 (1986) 21 suppl

[18] Schmidt W, D Heberling, F Kubl: Antepartum ultrasonographic diagnosis of conjoined twins in early pregnancy. Am J Obstet Gynecol 139 (1981) 961

[19] SIEGFRIED MS, GF KoPTIK: Prenatal sonographic diagnosis of conjoined twins. Postgrad Med 73 (1983) 317

[20] VAughn TC, LC Powell: The obstetrical management of conjoined twins. Obstet Gynecol 53 (1979) 67 suppl

[21] Wilson RL, CL Cetrulo, MS Shaub: The antepartum diagnosis of conjoined twins by the use of diagnostic ultrasound. Am J Obstet Gynecol 126 (1976) 737

[22] Wood MJ, HE Thompson, FM Roberson: Realtime ultrasound diagnosis of conjoined twins. $J$ Clin Ultrasound 9 (1981) 195

Received June 25, 1989. Accepted July 6, 1989.

Dr. Waldo H. Sepúlveda

Casilla 2407, Apartado 10

Concepción, Chile 


\section{Trace Element Analytical Chemistry in Medicine and Biology · Volume 5}

Proceedings of the Fifth International Workshop

Neuherberg, Federal Republic of Germany, April 1988

Editors Peter Brätter · Peter Schramel

1988. $17 \mathrm{~cm} \times 24 \mathrm{~cm}$. XVII, 666 pages. Numerous illustrations. Hardcover. DM 330,-; approx. US \$188.00 ISBN 3110113406

The subject matter of this volume is oriented towards the state of the art of trace element analytical techniques. Invited experts presented papers reporting on newer aspects of analytical methods, recent developments in preanalytical treatment of biological samples and the combination of analytical methods for speciation analysis. Aluminium and plantinum were elements of special interest. Attention was also paid to the trace element levels in body fluids and tissues as well as to the role of trace elements in metabolic processes and in human nutrition.

\section{Contents (Main Chapters)}

Newer Aspects of Analytical Methods - Preanalytical Steps: Sampling and Sample Treatment - Speciation Analysis - Trace Element Levels (and Reference Data) in Body Fluids and Tissues - Special Elements: Aluminium and Platinum - Nutrition and Food Stuffs · Trace Element Analysis in Diagnosis and Pathological States · Trace Element Metabolism · Subject Index · Author Index

\section{Also available}

\section{Trace Element Analytical Chemistry in Medicine and Biology}

Volume 1: 1980, XV, 851 pages. DM 180,-; approx. US \$ 100.00 Volume 2: 1983, XX, 1189 pages. DM 280,-; approx. US $\$ 160.00$ Volume 3: 1984, XVI, 763 pages. DM 240,-; approx. US \$ 140.00 Volume 4: 1987, XVI, 761 pages. DM 295,-; approx. US \$ 170.00

Prices are subject to change without notice

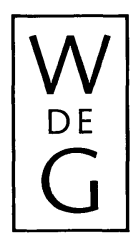

de Gruyter · Berlin · New York 